\title{
Pelatihan Pembuatan Balsam Stik Dari Bahan Herbal Dan Perintisan Sebagai Home Industri
}

\author{
Sri Rejeki Handayani, Ismi Rahmawati, Dewi Ekowati, Dwi Ningsih, Desi Purwaningsih \\ Fakultas Farmasi Universitas Setia Budi \\ E-mail: dwininksantoso@gmail.com
}

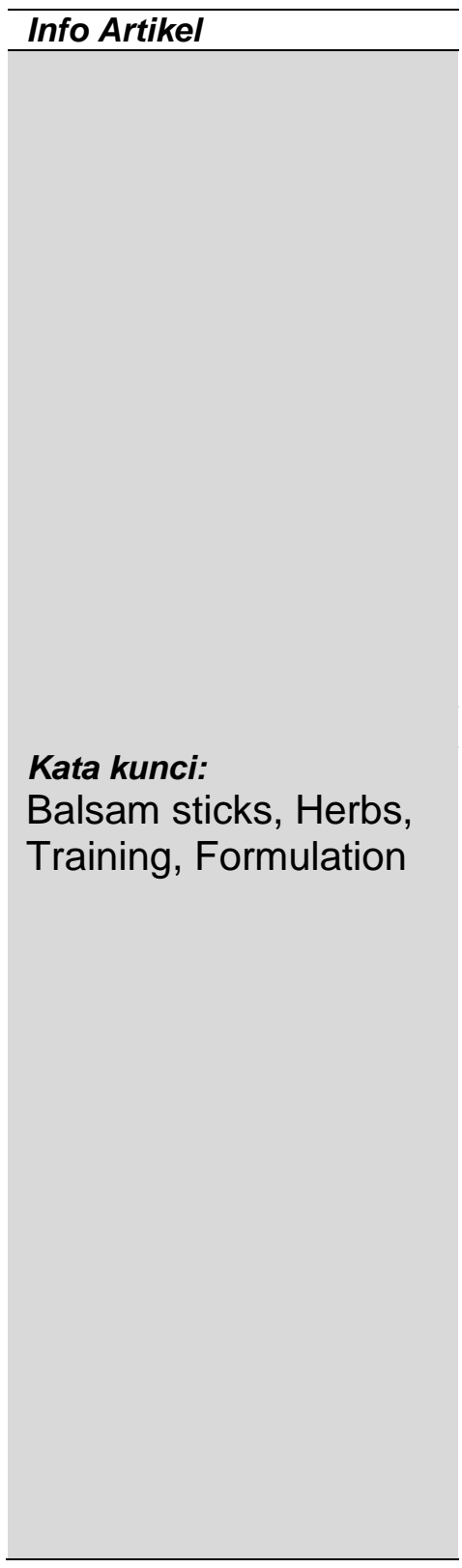

\begin{abstract}
Balm, a pharmaceutical product that is no stranger to the community, therefore, this product is one of the most potential commodities developed into a home industry that can improve the economy of the community. relatively simple balm formulation and easy in material, is very possible to be applied in the community. This article is a form of publication of community service that has been carried out on Tuesday, February 6, 2018, at RW XXII Bibis Luhur Kel. Nusukan Kec. Banjarsari Surakarta Central Java. This community service is entitled "training of sticks from herbal and pioneering industry as a home industry" which aims to provide understanding and skill through counseling, training, and application of herbal balsam in the form of sticks, and utilization in health by empowering natural resources optimally, produce new products, besides can be made for self-use, sticks balm is a product that is very much needed by the community, so it is possible to develop its production in the scale of home industry to improve the economy of the community.

\begin{tabular}{l}
\hline Abstrak \\
\hline Balsam, merupakan produk farmasi yang tidak asing bagi \\
masyarakat, karena itu, produk ini merupakan salah satu \\
komoditas yang sangat pontensial dikembangkan menjadi home \\
industry yang dapat meningkatkan perekonomian masyarakat. \\
Pembuatan balsam yang relative sederhana dan bahan yang \\
mudah, sangat memungkinkan diaplikasikan di masyarakat.Artikel \\
ini merupakan bentuk publikasi dari pengabdian kepada \\
masyarakat yang telah dilakasanakan pada hari Selasa, 6 \\
Februari 2018 di RW XXII Bibis Luhur Kel. Nusukan Kec. \\
Banjarsari Surakarta Jawa tengah. Pelatihan pembuatan balsam \\
stik dari bahan herbal dan perintisan sebagai home industri” ini \\
bertujuan untuk memberikan pemahaman dan ketrampilan melalui \\
penyuluhan, pelatihan, dan aplikasi pembuatan balsam berbahan \\
herbal dalam bentuk stik, serta pemanfaatannya di bidang \\
kesehatan dengan memberdayakan sumber daya alam secara \\
optimal, menghasilkan produk baru, yang selain dapat dibuat \\
untuk dipakai sendiri, balsam stik merupakan produk yang sangat \\
banyak dibutuhkan masyarakat, sehingga sangat memungkinkan \\
untuk dikembangkan produksinya dalam skala industri rumah \\
tangga untuk meningkatkan perekonomian masyarakat.
\end{tabular}
\end{abstract}

\section{PENDAHULUAN}

Bibis Luhur adalah sebuah perkampungan yang berada tepat di belakang lokasi kampus Universitas Setia Budi. Kampung dengan kepadatan penduduk yang tinggi dan mayoritas warga kampung adalah buruh pabrik dengan tingkat penghasilan yang rendah. Pengangguran juga masih banyak dikampung ini. Dengan tingkat perekonomian yang rendah, secara tidak langsung juga berdampak terhadap 
kesadaran akan perawatan kesehatan yang masih tergolong perawatan kesehatan tergolong rendah.

Sesuai dengan RENSTRA atau Rencana Strategis Pengabdian kepada Masyarakat tahun 2016-2020 yaitu optimalisasi potensi wilayah yang dapat digunakan untuk peningkatan kesehatan maka akan diadakan pelatihan pembuatan balsam stik di masyarakat untuk meningkatkan kesejahteraan dan kesehatan masyarakat. Balsem ( Balm ) adalah obat gosok yang dioleskan untuk kulit dengan bentuk sediaan semi padat.. Penggunaan balsam akan menimbulkan rasa panas pada otot, menyebabkan relaksasi dan menstimulasi aliran darah sehingga rasa sakit akan berkurang.

Permasalahan yang dihadapi Mitra adalah tingkat perekonomian yang rendah serta pengetahuan dan kesadaran akan perawatan kesehatan yang masih tergolong rendah. Perlu pelatihan dan motivasi untuk menciptakan peluang usaha rumahan (home industri) dengan produk-produk yang dapat digunakan untuk merawat kesehatan sehari-hari sekaligus menambah income penduduk. Perlu pelatihan dan motivasi untuk menciptakan peluang usaha rumahan (home industri) dengan produk yang dapat digunakan untuk merawat kesehatan anak sehari-hari sekaligus menambah income penduduk yaitu balsam stik sebagai peghilang nyeri dan penghangat.

\section{METODE PENELITIAN}

Metode pelaksanaan pengabdian pada masyarakat ini mencakup 3 (tiga) tahap kegiatan persiapan, pelaksanaan, dan evaluasi sebagai berikut :

\section{Persiapan}

Pada tahap persiapan, dilakukan survey penentuan lokasi dan sasaran, analisis kebutuhan kegiatan, dan penyusunan materi kegiatan.

\section{Pelaksanaan}

Pada tahap pelaksanaan, dilakukan penyuluhan, cara pembuatan balsam stik yang komposisi zat aktifnya berasal dari tanaman. Setelah materi dipahami, dilakukan pelatihan tentang bagaimana cara membuat balsam stik yang komposisi zat aktifnya berasal dari tanaman. Melakukan pendampingan kelompok ibu rumah tangga dalam proses pembuatan balsam stik

\section{Evaluasi}

Untuk melihat keberhasilan Program Pengabdian bagi Masyarakat ini dilakukan evaluasi hasil pelatihan produk balsam stik yang dihasilkan kelompok ibu rumah tangga

\section{PEMBAHASAN}

Kegiatan pengabdian diawali dengan komunikasi dengan pihak kelurahan dan RW sebagai tempat pengabdian. Sebelum dilakukan pelatihan pembuatan balsam stik terlebih dahulu dilakukan orientasi untukmendapatkan formula yang optimal, dilanjutkan dengan pelatihan pembuatan balsam stik dari bahan herbal yang dipraktekkan bersama dengan ibu-ibu warga RW 22 Nusukan. Program kegiatan pengabdian masyarakat ini dihadiri oleh 30 peserta warga RW XXII Kelurahan Nusukan. Untuk mempermudah peserta memahami materi pelatihan dilengkapi dengan brosur formula bahan balsam dan cara mengerjakannya. 
Balsam minyak telon pembuatanya cukup mudah dan bahan-bahan juga mudah didapatkan sehingga dapat dibuat sendiri di masyarakat. Dengan dibuat sendiri balsam telon salah satu keuntunganya dapat disesuaikan dengan keinginan misalnya dalam hal panas yang dihasilkan sehingga meningkatkan kenyamanan pada bayi, selain itu juga dapat dikembangkan menjadi home industri. Bahan herbal yang digunakan dala, pembuatan balsam stik dapat divariasikan sesuai keinginan..Balsam telon juga dapat ditambahkan bahan yang berfungsi mengusir nyamuk misalnya minyak sereh, sehingga dapat menghangatkan dan sekaligus mengusir nyamuk.

Alat yang digunakan adalah panci, gelas ukur, sendok tanduk, neraca, teko air minum, gelas ukur, batang pengaduk, kompor dan tissue. Bahan yang digunakan yaitu minyak zaitun , minyak sereh, minyak adas, Methyl Salisilat, Oleum Pepermint, Champora, Mentol, Parafin Padat, Cera Alba, dan vaselin Album. Minyak Kayu Putih Minyak ini diperoleh dengan penyulingan daun segar dan pucuk ranting tanaman kayu putih (Eucalyptus globulus), dan diketahui mengandung bahan aktif sineol mi-nimal $70 \%$. Minyak kayu putih berwarna kuning pucat, bau aromatic seperti kamfer, dan rasa pedas seperti kamfer. Minyak kayu putih berkhasiat sebagai karminatif, obat batuk, antijamur, selesma, sinusitis, dan antiiritasi (mengurangi rasa sakit pada kulit).

Sereh wangi diduga berasal dari Srilangka. Nama latinnya adalah Cymbopogon nardus L., termasuk dalam suku Poaceae (rumput-rumputan). Varietas sereh wangi yang paling dikenal adalah varitas Mahapegiri (java citronella oil) dan varitas Lenabatu (cylon citronella oi). Varitas Mahapegiri mampu memberikan mutu dan rendemen minyak yang lebih baik bandingkan varitas Lenabatu. (Data Sbdit Tanaman Atsiri, Dittansim, 2008). Proses pengambilan minyak sereh wangi di Indonesia biasanya dilakukan melalui proses penyulingan selama $3-4$ jam. Rendemen rata-rata minyak sereh wangi sekitar $0,6-1,2 \%$ tergantng jenis sereh wangi serta penanganan dan efektifitas penyulingan. Komponen terpenting dalam minyak sereh wangi adalah sitronellal dan geraniol. Minyak sereh wangi juga dapat digunakan sebagai penolak gigitan nyamuk. Minyak sereh wangi mengandung sitronela $(35 \%)$ dan geraniol (35-40\%). Zat sitronelal ini memiliki sifat racun kontak. Sebagai racun kontak, ia dapat menyebabkan kematian akibat kehilangan cairan secara terus-menerus sehingga tubuh nyamuk kekurangan cairan hal ini dapat terjadi setelah nyamuk mencium aroma ekstraks sereh wangi, tanaman ini mempunyai aroma yang sangat wangi akan menyebabkan nyamuk menolak karena baunya (Pinardi et al, 2010).

Adas (Foeniculum vulgare) merupakan tanaman herba tahunan. Di Indonesia, tanaman ini banyak dimanfaatkan sebagai bumbu masak, lalapan, obat herbal tradisional, dan juga sebagai bahan obat gosok untuk masuk angin, karena aromanya yang wangi dan minyak atsirinya terasa hangat. Adas mengandung minyak atsiri sekitar 6\%. Minyak atsirinya mengandung bahan utama anethol (50$80 \%)$, limonene $(5 \%)$, fenchone $(5 \%)$, dan bahan lainnya seperti estragol (methyl chavicol), safrol, alpha pinene, camphene, beta pinene, dan beta myrcene (Rusmin dan Melati, 2007). Minyak adas dikenal sebagai salah satu allround flavouring agent karena memiliki aroma yang khas, menarik, dan banyak digunakan untuk pewangi dalam industri kosmetik seperti sabun, parfum, detergen, dan lainnya. Menurut Ketaren (1980), minyak adas mengandung bahan aktif utama anethol sebesar 50$60 \%$ yang diperoleh melalui penyulingan. Salah satu khasiat anetol adalah sebagai karminatif (Dalimartha, 1999). Minyak atsiri adas bersifat repellent terhadap serangga (Grainge dan Ahmed, 1987). 
Minyak zaitun terdiri dari zat-zat minyak yang dinamakan glesiredat (ester) dengan persentase $97 \%$ dan zat-zat minyak lainnya. Minyak zaitun juga mengandung berbagai vitamin (seperti vitamin A, B, C, D, dan vitamin E), zat-zat pewarna (seperti klorofil, xanthophyll), serta berbagai zat aromatic yang menimulkan aroma dan rasa yang khas. Terakhir minyak zaitun mengandung sejumlah kecil mineral (besi, magnesium, dan kalsium), koloid, resin, dan air. Setiap 100 gram zaitun mengandung zat-zat sebagai berikut : 90 gram protein, $61 \mathrm{mg}$ kalsium, $22 \mathrm{mg}$ magnesium, $17 \mathrm{mg}$ fosfor, $1 \mathrm{mg}$ besi, 0,22 $\mathrm{mg}$ tembaga, 36 $\mathrm{mg}$ klorin, 4,4 gram serat, $180 \mu \mathrm{g}$ beta karotin, 3-30 mg vitamin K. Menurut Surtiningsih (2005) minyak zaitun selain digunakan untuk berbagai masakan juga berkhasiat untuk perawatan kecantikan. Minyak zaitun kaya vitamin $\mathrm{E}$ yang merupakan anti penuaan dini. Minyak zaitun juga bermanfaat untuk menghaluskan dan melembabkan permukaan kulit tanpa menyumbat pori. Minyak zaitun merupakan pelembab yang baik untuk melembabkan kulit wajah dan tubuh. Selain itu, minyak zaitun bermanfaat untuk melepaskan lapisan sel-sel kulit mati. Mentol adalah suatu senyawa yang terdapat dalam minyak atsiri spesies mentha, secara khusus digunakan untuk nyeri kepala. Mentol berbentuk kristal, tidak berwarna, bau tajam seperti permen, rasa panas dan aromatik. Mentol dapat dikenali dengan mudah dengan mencium baunya yang khas, mentol sering digunakan dalam pembuatan minyak gosok atau balsam karena mempunyai rasa hangat.

\section{Prosedur pembuatan balsam:}

1. Parafin padat, cera alba dan vaselin alba dimasukkan dalam teko (kaca/stainlees/aluminium) dicampur kemudian dipanaskan dengan cara di tim (diatas panci yang sudah diisi air).

2. Minyak kayu putih, minyak peppermint, methyl salisilat, camphor dan mentol dicampur dalam gelas kaca.

3. Campuran No 1 dan No 2 dicampur menjadi satu dalam keadaan masih panas, aduk dengan sendok sampai tercampur rata.

4. Tuang dalam pot salep/kemasan, tunggu sampai dingin.Tutup pot salep dan balsam siap digunakan (gambar 5).

\section{Khasiat dan kegunaan balsam}

Balsam mempunyai kegunaan yang beragam. Berdasarkan bahan aktifnya yaitu minyak atsiri, balsam obat gosok umumnya digunakan untuk meringankan sakit kepala, sakit perut, sakit gigi, menghilangkan gatalgatal akibat gigitan serangga, pegal-pegal, pilek dan hidung tersumbat karena flu, juga untuk pijat dan kerik. Berdasarkan pengalaman ditemukan bahwa sebagian minyak atsiri bekerja sebagai relaksan, sedatif (penenang), mempertajam daya ingat dan sebagian meningkatkan sirkulasi darah. Cara penggunaannya yaitu dengan digosokkan atau dioleskan secara merata pada bagian yang terasa sakit hingga hangat dan terasa menyegarkan (Anonim, 2006). Kegiatan pelatihan pembuatan balsam stik dari bahan herbal di Bibis Luhur RW 22, Nusukan, Surakarta diselenggarakan pada tanggal 06 Februari 2018 dengan metode pemberian materi tentang manfaat balsam dengan bahan aktif herbal yang secara mudah diperoleh dan relatif aman karena berasal dari tanaman, dan diberikan pelatihan pembuatannya. Selanjutnya ibu-ibu praktek membuat balsam stik yang dilakukan secara mandiri dengan pendampingan.

Ketertarikan dan peran aktif dari para peserta terhadap pelatihan pembuatan balsam herbal berbentuk stik ini diharapkan bisa menjadi peluang usaha rumah tangga di lingkungan RW 22 Kalurahan Nusukan, yang merupakan salah satu target luaran dalam kegiatan pengabdian pelatihan pembuatan balsam herbal yang 
dikemas dalam bentuk stik. Pelatihan pembuatan balsam herbal yang dikemas dalam bentuk stik sebagai rintisan home industri ditindaklanjuti dengan menghibahkan peralatan berupa kompor, tabung gas, panci, pengaduk, timbangan, wadah stik balsam, dan bahan-bahan pembuat balsam yang nantinya diharapkan warga bisa membuat balsam tersebut untuk kepentingan sendiri dan harapannya bisa memproduksi dalam jumlah besar untuk diperdagangkan sehingga bisa menambah penghasilan.

\section{PENUTUP}

Berdasarkan hasil diatas dapat disimpulkan bahwa:

1. Kegiatan pengabdian pelatihan pembuatan balsam herbal bentuk stik di RW 22 Nusukan, Banjarsari, Surakarta terlaksana dengan lancar.

2. Peserta antusias dengan pembuatan balsam denganinovasi wadah berupa stik.

3. Peserta berperan aktif dalam pelatihan dan mampu membuat produk secara mandiri.

\section{REFERENCES}

Agoes, A. 2010. Tanaman Obat Indonesia. Salemba Medica. Palembang

Anonim, 2006, Cara Mudah Membuat Balsam Obat Gosok, Warta Penelitian dan Pengembangan Pertanian, Vol. 28, No.6.

Arisandi, Y. dan Andriani, Y. 2008. Khasiat Tanaman Obat. Pustaka Buku Murah. Jakarta

Anief. (1999). Sistem Dispersi Formulasi Suspensi dan Emulsi. Yogyakarta:Gadjah Mada University Press.Hal 57-58, 64-65

Anief. (2005). IImu Meracik Obat. Yogyakarta:Gadjah Mada University Press.Hal 72 ,132

Balsam. M.S. (1972). Cosmetic Science and Technology. Second Edition. New York: John Wiley and Sons: p. 211, 216

Dalimartha, S. 2003. Atlas Tumbuhan Obat Indonesia. Jilid 3. Puspa Swara. Jakarta

Dalimartha, S. 2004. Tumbuhan Obat Indonesia. Jilid 1. Trubus Agriwidya. Jakarta

Dalimartha, S. 2005. Tanaman Obat di Lingkungan Sekitar. Puspa Swara. Jakarta

Depkes RI. (1995). Materia Medika Indonesia. Jilid VI. Jakarta: Departemen Kesehatan RI. Hal. 319-325.

Ditjen POM. (1979). Farmakope Indonesia. Edisi III. Jakarta: Departemen Kesehatan RI. Hal. 33

Guenther, E. (1990). The Essential Oils. Penerjemah: Ketaren, R.S. Minyak Atsiri.

Gunawan, D. dan Mulyani, S. (2004). Ilmu Obat Alam (Farmakognosi). Jilid I. Jakarta: Penerbit Penebar Swadaya. Hal. 123.

Hariana, A. 2008. Tumbuhan Obat dan Khasiatnya. Cetakan Kelima. Penebar Swadaya. Jakarta 